\title{
Views and Comments
}

\section{Modelling Interest-Free Economy, A Study in Macro-Economics and Development}

In recent years there has been numerous Islamic publications in both social and economic fields trying to establish their theoretical and empirical basis according to Islamic principles Modelling Interest-Free Economy, A Study in Macro-economics and Development by Dr. Muhammad Anwar is one book which is a laudable study in economics, applying particularly the mudaraba system to the macro-economic level. Although it is really valuable study, I would like to express my opinions on the following points.

1) Regarding the technical points, it would have been useful for the reader if the sources used as reference had been given as footnotes. It is difficult to refer back to the sources.

2) "Muslim countries are reforming their financial systems in the light of Islamic teachings. Islamic financial institutions conduct their operations in ways that steer clear of interest and conform to the Sharia, the Islamic code of law and ethics (p. 7)." In such studies, it would be useful to draw a clear line between trade activities and partnerships and the banking system. Since Islamic countries and Muslim scholars are just now trying to develop a new banking system according to Islamic principles, we should be strictly careful when using the term "Islamic Banks." In contrast with some Muslim scholars, for similar reasons we should also be careful when putting forward the mudaraba system as the basis for a banking or economic system. Instead of calling these institutions "Islamic" it would be more proper to use such terms as "Interest-Free Commercial Institutions", "Interest-Free Financial Institutions", "InterestFree Credit Institutions (Corporations)," etc.

3) The mudaraba contract as a form of partnership is directly related to trading activities. The involvement of the banking system in trade activities by establishing partnerships with certain firms through mudaraba contracts can severely distort the free competition in the market system which is encouraged by the Prophet (ȘAAS). Banks are institutions in which huge amounts of financial resources are accumulated. As the banks enter the market to make commercial transactions, even though in the forms of mudaraba, musharaka or murabaha, this involvement will likely 
distort the free competition which is important for price determination. Worse, their participation could cause monopolization of the market and could also impede in the long-run the social balance. Money is a public good provided by the government and given value by the people. To make it a commercial commodity means that the economic system will be dropped into the trap which the capitalist system is caught in resulting in some of the economic and social diseases which we are trying to eliminate from our society. Because of these reasons, giving commercial functions to the banks can create another way of exploitation as it encourages undue concentration of wealth in a few hands. It is also doubtful that in the long-run it contributes to the welfare of the society as a whole, unless some credit criteria are developed.

4) Since this need is felt by the author, he says "It is imperative that equal opportunity be given to all people (p. 7)." But, if it is not possible for the people to have credit opportunity from these financial institutions, how can this equality be achieved? He also says "Islam does not overemphasize material incentives because physical rewards are seen as a means rather than an end in themselves (p. 7)". Although in this study it seems that more emphasis has been given to physical rewards, I agree with the idea that a credit institution should be organized and motivated according to the principle of this judgement. To achieve this, some credit criteria could be developed. For example:

a) Feasibility of the project. It can be decided by an expert committee.

b) The amount of taxes paid by the credit demander.

c) The number of employees working in the firm.

d) The improvement in productivity, etc.

To encourage savings, the financial resources deposited in these institutions could be given a tax exemption. Tax exemption would be an effective incentive to attract idle financial resources to the banks.

5) "The government may also sell its own mudarabas to obtain funds for financing its budget deficits rather than investing directly in profitable industrial or commercial activities (p. 37)." It is difficult to support government participation in business activities using mudarabas for financing its deficits. One of the most important problems which must be investigated is whether government should be allowed to have a deficit 
in its budget. Except in extraordinary conditions, is it reasonable or truthful to govern the country incurring budget deficits? If governmental participation in business mudarabas leads to discretionary policy implementation by the politicians, it is not possible to agree with the author's suggestion. Government intervention in private economic activities or unwarranted increases in its own economic functions will in time cause serious resource misallocations and diminished social well-being.

To emphasize mudaraba partnerships in the banking system as if all economic problems will thereby be magicly solved would be a mistake. The most important duty of the contemporary Muslim scholar is to develop a just monetary system as an alternative to the system current in the world. Most of the economic and social problems of the world come from the present monetary system.

Sabri Tekir

University Faculty of Economics and Administrative Sciences

Izmir, Turkey

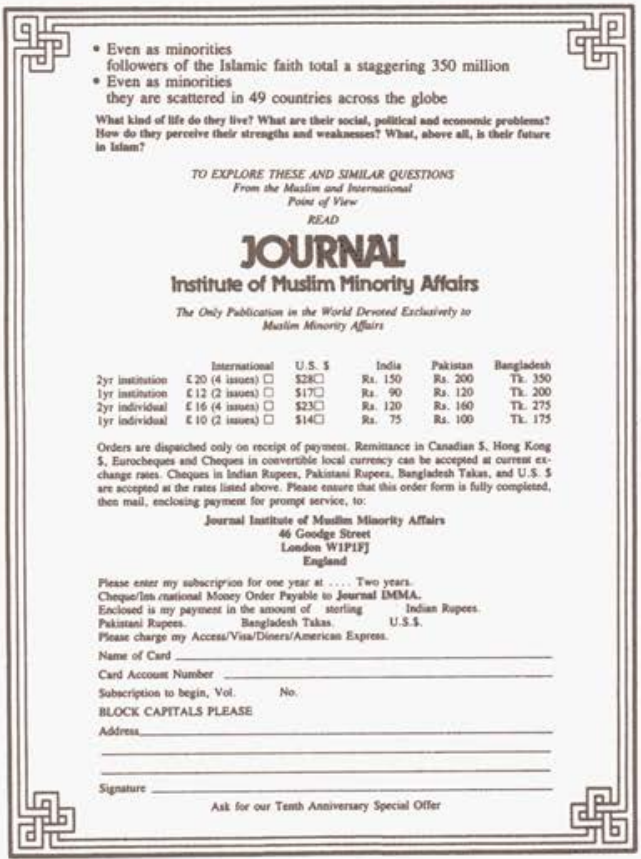

